\section{Barn dør av forgiftet legemiddel i Nigeria}

84 barn har dødd av forgiftning i Nigeria etter å ha fått «My Pikin» en sirup med paracetamol mot smerte ved tannfrembrudd (1).

Sirupen inneholdt kjemikaliet dietylenglykol som blant annet brukes i motorkjølevæske. Det har samme smak og lukt som glyserol som ofte brukes i legemidler, men er billigere (2). Det er derfor blitt brukt i forfalskede medikamenter som en erstatning for glyserol. Foreløpig er 111 barn mellom to og sju år blitt syke, med symptomer som feber, oppkast og diaré, og 84 av disse barna har dødd.

Forgiftet «My Pikin» - som betyr «min baby» - ble først oppdaget i november 2008 da små barn begynte å dø av organsvikt flere steder i Nigeria. National Agency for Food, Drug Administration and Control (Nafdac), satte da en stopper for fabrikanten Barewa Pharmaceuticals i Lagos. Nafdac har også bedt foreldre i Nigeria om ikke å bruke liknende produkter før resten av beholdningen er funnet.

- Regjeringen vil gjøre alt de kan for å finne svar på de mange spørsmålene nigerianere vil ha og også sørge for at en slik uheldig situasjon ikke gjentar seg, sier Nigerias nye helseminister, Babatunde Osotimehin. - Hvert eneste nigerianske barn som dør, er et stort tap for landet, sier han.

\section{Oda Riska}

oriska@hotmail.com

Tidsskriftet

\section{Litteratur}

1. Nigeria baby poison deaths rise. $B B C$ news 6.2. 2009. news.bbc.co.uk/1/hi/world/africa/ 7874723.stm (13.2.2009).

2. Polgreen L. 84 Children are killed by medicine in Nigeria. The New York Times 6.2. 2009. www.nytimes.com/2009/02/07/world/africa/ 07nigeria.html?_r=1\&scp=1\&sq=nigeria\% 20 baby\%20medicine $\&$ st=cse (13.2.2009).

\title{
Høy mødredødelighet i verdens fattigste land
}

\author{
I verdens fattigste land er livstidsrisikoen for å dø som følge av svanger- \\ skaps- eller fødselskomplikasjoner 300 ganger større enn i i-land. \\ Det er konklusjonen i en ny rapport om barne- og mødrehelse fra \\ UNICEF. Barn $f \varnothing \mathrm{dt}$ i et $\mathrm{u}$-land har 14 ganger større sannsynlighet \\ for å dø i løpet av første levemåned enn barn født i et i-land.
}

Mens det i mange land har vært fremgang $i$ arbeidet med å bedre barneoverlevelse de siste årene, har det vært mindre fremgang med å redusere mødredødelighet. Det er estimert at om lag ti millioner kvinner har dødd av komplikasjoner relatert til svangerskap og fødsel siden 1990. Ifølge UNICEFs rapport er skillet mellom i-land og u-land, særlig verdens fattigste land, kanskje større for mødredødelighet enn for noe annet helseproblem (1).

Livstidsrisikoen for å dø som følge av et svangerskap er 1: 7 i Niger, sammenliknet med 1: 4800 i USA og 1:48 000 i Irland. Landene med høyest mødredødelighet er Niger, Afghanistan, Sierra Leone, Chad, Angola, Liberia, Somalia, Den demokratiske republikken Kongo, Guinea-Bissau og Mali.

I Niger og Malawi er barnedødeligheten

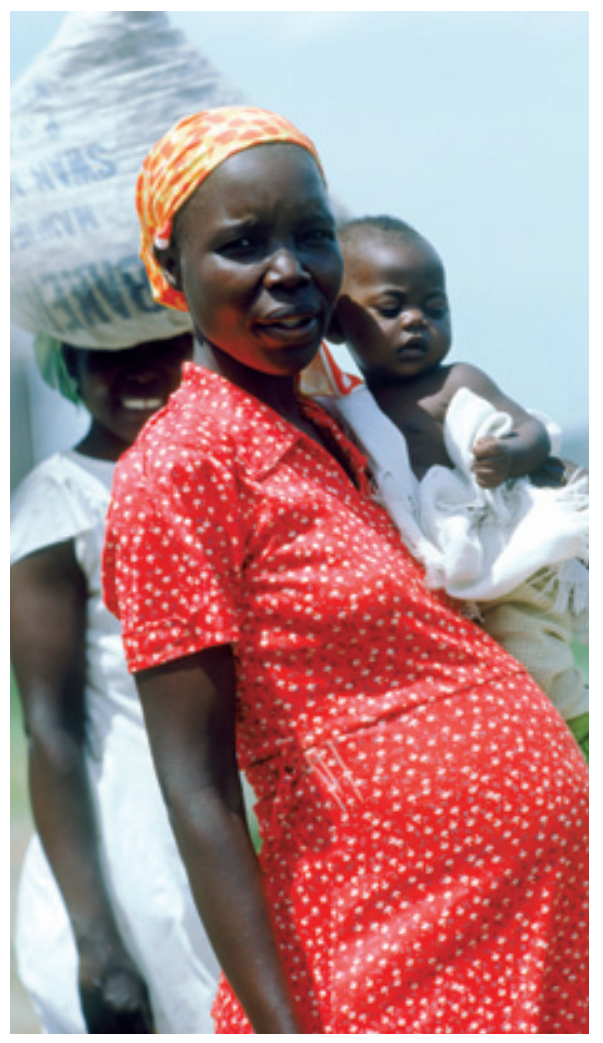

blitt nesten halvert fra 1990 til 2007, og i Bangladesh er den blitt redusert med mer enn halvparten. Den samme fremgangen har ikke skjedd innen mødrehelse.

- Blant den halve millionen kvinner som dør hvert år på grunn av svangerskaps- eller fødselskomplikasjoner, er 70000 mellom 15 og 19 år, forteller toppsjef i UNICEF Ann M. Veneman (2).

For å redusere mødredødeligheten trengs bedre helsetjenester som når frem til kvinnene som trenger dem. Rapporten fremhever også viktigheten av utdanning.

- Å redde mødre og deres nyfødte krever mer enn helseintervensjoner. Å utdanne jenter er avgjørende for å bedre barne- og mødrehelse og gagner også familier og samfunn, sier Veneman.

\section{Oda Riska}

oriska@hotmail.com

Tidsskriftet

\section{Litteratur}

1. UNICEF. The state of the world's children 2009. New York: UNICEF, 2008. Maternal and newborn health. www.unicef.org/sowc09/report/report.php (9.2.2009).

2. UN News Centre. Pregnancy 300 times deadlier in world's poorest nations, says UNICEF. www. un. org/apps/news/story.asp? NewsID=29551\&Cr= UNICEF\&Cr1 (9.2.2009). 